\title{
Liquid Biopsy: Approaches to Dynamic Genotyping in Cancer
}

\author{
Nikolas von Bubnoffa,b \\ a Department of Hematology, Oncology and Stem Cell Transplantation, Medical Center University of Freiburg, Freiburg i.Br., Germany; \\ ${ }^{\mathrm{b}}$ German Cancer Consortium (DKTK) and German Cancer Research Center (DKFZ), Heidelberg, Germany
}

\section{Keywords \\ Biomarker · Molecular diagnosis · Liquid biopsy}

\section{Summary}

Malignant tumors release tumor cells and fragments of nucleic acids into the bloodstream. Liquid biopsies are non-invasive blood tests that detect circulating tumor cells (CTC) and circulating nucleic acids such as mRNA, microRNA, and cell-free circulating tumor DNA, also known as ctDNA. The presence of ctDNA or CTCs in the plasma has prognostic impact. Since ctDNA contains tumor-specific mutations, its detection in the blood or other body fluids can predict response to treatment and relapse. Moreover, repeated analysis and quantitation of ctDNA can inform about changes in clonal composition over time and thus allow dynamic treatment stratification. Today, the routine clinical use of liquid biopsy diagnostic tests is limited; however, in the near future, they might become commonly used sensitive and specific biomarkers to guide cancer treatment. This review will summarize recent findings on the use of ctDNA for monitoring response to therapy and dynamic genetic treatment stratification.

(c) 2017 S. Karger GmbH, Freiburg

\section{Introduction}

The majority of cancers contain numerous genetic variants that determine the oncogenic behavior of tumor cells $[1,2]$. The knowledge of critical driver mutations and key pathways as rational drug targets has led to the development of molecular targeted cancer therapies including kinase inhibitors and immune checkpoint in- hibitors. Consequently, cancer treatment is shifting from an entitydriven approach to molecular-guided individualized decisionmaking and patient care [3].

In contrast, the development of non-invasive methods to detect and monitor tumor growth and treatment response continues to be a major challenge in oncology. Response to therapy is evaluated based on diagnostic imaging and blood-based protein biomarkers. Current imaging techniques including positron emission tomography-computed tomography (PET-CT) display limited sensitivity and specificity $[4,5]$. Pseudoprogressions seen with immune checkpoint inhibitors have challenged existing RECIST criteria and have led to the development of immune-related response criteria [6]. Tumor biomarkers are hampered by low sensitivity, low positive predictive value, and low specificity, since patients with low tumor load are often false-negative, and false-positive findings result from release by non-cancerous tissues and comorbid diseases. This includes well-established protein biomarkers such as prostate-specific antigen (PSA) in prostate cancer, carcinoembryonic antigen (CEA) in colorectal carcinoma (CRC) $[7,8]$, and S100 and lactate dehydrogenase $(\mathrm{LDH})$ in melanoma $[9,10]$. Thus, despite their widespread use, available protein biomarkers will often not detect relapse or progression of cancer. Consequently, treatment changes are often not instituted before clinical or radiologic progression is evident.

Tumors release tumor cells and nucleic acid content into the circulation [11] (fig. 1A). Circulating tumor cells (CTCs) and circulating tumor (ct)DNA can be detected and quantified (fig. 1B). Although the detection and quantification of ctDNA is hampered by its sometimes extremely low levels, ctDNA is unique in its tumor-specific origin: It contains tumor-specific mutations allowing strict discrimination from normal cell-free (cf)DNA, thus resulting in high-specificity detection, provided that accurate and sensitive assays are used. This opens up a broad range of novel applications (table 1) not covered by currently available biomarkers, including the possibility to depict changes in clonal genetic composition and to adapt treatment in a dynamic fashion (fig. 1B).

\section{KARGER}

() 2017 S. Karger GmbH, Freiburg 


\section{Release of ctDNA}

The presence of cfDNA in blood plasma and serum was first recognized in 1948 [12]. Cells undergoing necrosis or apoptosis release nucleic acid content into the bloodstream. Consequently, cfDNA is elevated after exercise, trauma, and inflammation, and in patients with cancer [13-15]. The presence of fetal DNA in maternal blood has recently allowed the development of commercial tests for prenatal assessment of germline fetal changes $[16,17]$. DNA fragments released by tumor cells constitute cellfree ctDNA. Mechanisms of release by tumor cells include passive shedding by necrotic or apoptotic cells and possibly also active release [18] (fig. 1A). Fragments of ctDNA are often 160-200 bp in length, and the presence of nucleasomal laddering suggests the majority to be derived from cells undergoing apoptosis [19]. The amount of DNA released into the circulation correlates with cell turnover and hence tumor burden [19], and varies between tumor entities [20]. The fraction of cfDNA derived from a tumor varies between 0.01 and $90 \%[21,22]$ and might depend on the

Table 1. Possible applications of circulating tumor (ct)DNA biomarkers in cancer patients

Early diagnosis and screening

Prognostic stratification

Treatment stratification

Monitoring of response to treatment

Detection of minimal residual disease

Clonal heterogeneity and treatment resistance size of the tumor and its location and vascularization [23]. Tumor nucleic acid content in blood samples can be accessed either by analyzing the ctDNA compartment or by genotyping CTCs $[20,24,25]$.

\section{Detection of ctDNA}

The low abundance of ctDNA and the varying background of non-cancer-derived cfDNA hamper ctDNA monitoring and require highly sensitive and specific techniques for accurate detection and quantification. This is technically challenging, especially at the early tumor stages. Standard Sanger sequencing will not be sensitive enough in most cases. A number of different sequencing technologies have been demonstrated to specifically detect and quantify ctDNA with a sensitivity of $0.01 \%$ or lower, including digital polymerase chain reaction (dPCR) [26], beads, emulsion, amplification, and magnetics (BEAMing) - a modified dPCR technique [27], ligation (L)PCR [28], and recently targeted sequencing strategies such as amplicon deep sequencing [29] or hybrid-capture deep sequencing [30]. Using these technologies, ctDNA can be detected in $50 \%$ of early-stage cancers and in up to $100 \%$ of metastatic cancers [20, 21, 30]. In the last years, technologies based on dPCR and targeted sequencing have proven to be most suitable for liquid biopsy applications. Both technologies allow very sensitive detection of allele variants, down to a resolution of $0.005 \%$. dPCR can simultaneously detect up to 4 different mutations [31]. Thus, dPCR might be most suitable as a robust point-of-care platform for the detection and monitoring of non-synonymous stereotypic mu-

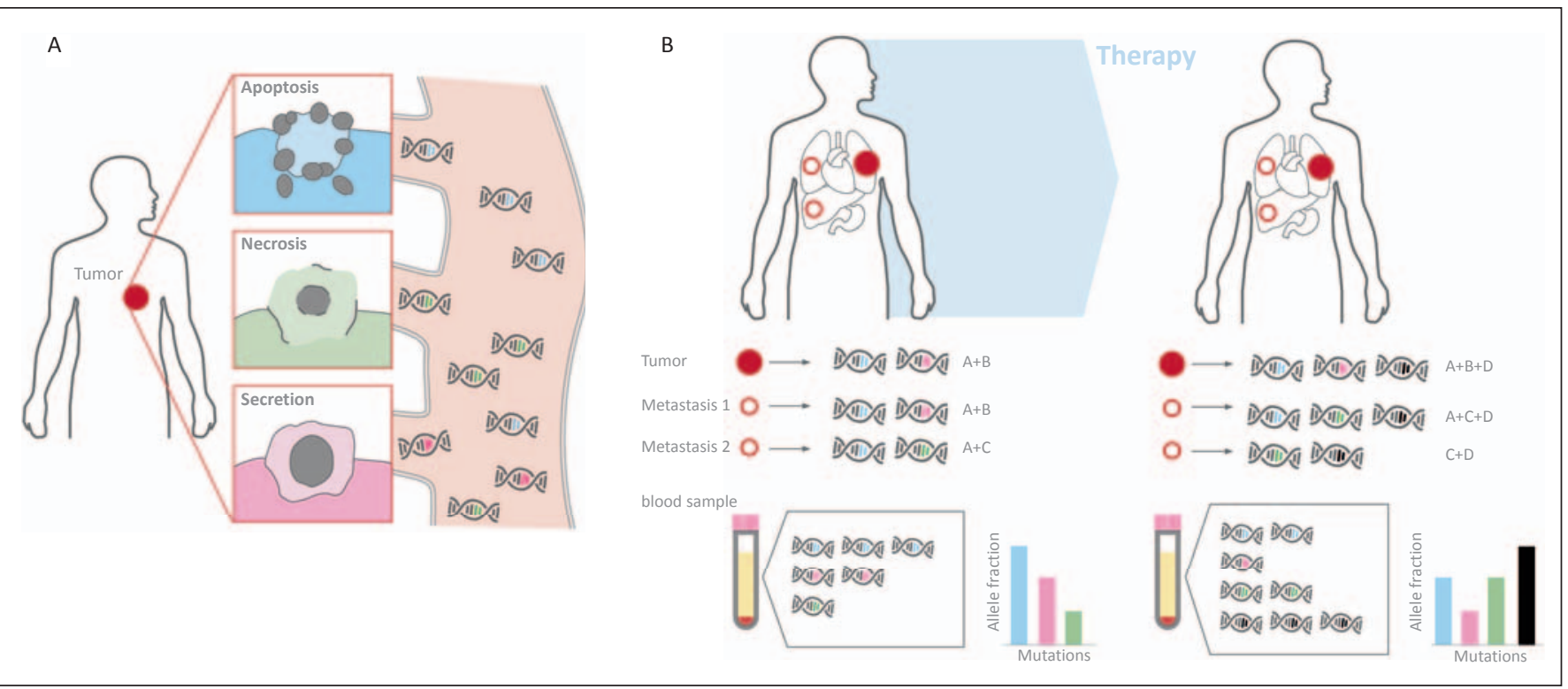

Fig. 1. Tumors shed nucleic acid content into the circulation, either passively by apoptosis and necrosis or actively. A Small fragments of cell-free circulating tumor (ct)DNA can be detected and quantified in blood samples. The presence of such mutated ctDNA fragments can inform about the genetic composition of a tumor, and their quantity can be used to monitor response to treatment. B Treatment will affect the clonal genetic composition of cancer. As specific tumor lesions may vary in their content of specific mutations, ctDNA shed from these lesions will represent this information. A blood sample will integrate ctDNA from all lesions and thus represent a dynamic picture of the clonal genetic composition over time. This information might be used to monitor response to treatment, predict relapse, and stratify treatment in a dynamic fashion. 
Table 2. Comparison of the sensitivity and specificity of detecting tumor-specific mutations in circulating tumor (ct)DNA with tissue as reference standard for different entities using various technologies

\begin{tabular}{|c|c|c|c|c|c|c|c|c|}
\hline & Breast & & & NSCLC & & & CRC & $\begin{array}{l}\text { NSCLC, GIST, } \\
\text { CRC, melanoma }\end{array}$ \\
\hline Reference & {$[49]$} & & & {$[30]$} & {$[59]$} & {$[54]$} & {$[22]$} & {$[41]$} \\
\hline Patients, $\mathrm{n}$ & 30 & & & 17 & 72 & 216 & 95 & 63 \\
\hline Stage(s) & IV & & & I-IV & III/IV & IV & IV & III/IV \\
\hline \multicolumn{9}{|l|}{ Marker } \\
\hline Name & PIK3CA, TP53 & CA $15-3$ & CTC & 139 genes & EGFR & EGFR & $\begin{array}{l}\text { KRAS, } \\
\text { BRAF }\end{array}$ & $\begin{array}{l}\text { EGFR, KRAS, } \\
\text { NRAS, BRAF, } \\
\text { KIT, PDGFRA }\end{array}$ \\
\hline Technique & amplicon seq/dPCR & ELISA & CellSearch ${ }^{\circledR}$ & hybrid-capture seq & cobas ${ }^{\circledR} /$ BEAMing & BEAMing & AS-qPCR & \\
\hline Sensitivity & $97 \%$ & $78 \%$ & $87 \%$ & $\begin{array}{l}100 \% \text { (stage II-IV) } \\
50 \%(\text { stage I) }\end{array}$ & $\begin{array}{l}82 \%(\text { exon } 19 \text { del }) \\
87 \%(\text { L858R) } \\
73 / 81 \%(\text { T790M) }\end{array}$ & $\begin{array}{l}82 \% \text { (exon } 19 \text { del) } \\
86 \%(\text { L858R) } \\
70 \%(\text { T790M) }\end{array}$ & $93 \%$ & $79 \%$ \\
\hline Specificity & NA & NA & NA & $96 \%$ & $\begin{array}{l}\text { 97\% (exon } 19 \text { del) } \\
97 \%(L 858 R) \\
67 / 58 \%(T 790 M)\end{array}$ & $\begin{array}{l}98 \%(\text { exon } 19 \text { del) } \\
97 \%(\text { L858R) } \\
69 \%(\text { T790M) }\end{array}$ & $98 \%$ & $100 \%$ \\
\hline
\end{tabular}

NSCLC = Non-small cell lung cancer; CRC = colorectal cancer; GIST = gastrointestinal stromal tumors; CTC = circulating tumor cells; AS-qPCR: allele-specific quantitative polymerase chain reaction; ELISA = enzyme-linked immunosorbent assay; BEAMing = beads, emulsion, amplification, and magnetics; $\mathrm{dPCR}$ = digital droplet PCR; seq = sequencing; NA = not applicable.

tations such as RAS in CRC or epidermal growth factor receptor (EGFR) mutations in lung cancer [31, 32]. However, each dPCR assay is limited to detecting 1 specific mutation site. In contrast, targeted sequencing of ctDNA will cover hundreds to thousands of amplicons in 1 assay read in an unbiased fashion [30,33]. Advantages include detection of subclonal mutations and analysis of changes in clonal composition over time. However, targeted sequencing of ctDNA is expensive and time-consuming, and requires customized protocols to allow an assay sensitivity of below $1 \%$ and to avoid false-positives [34].

\section{Tissue versus Liquid Biopsy}

Currently, sequencing analyses of tissue biopsies are the standard for genetic treatment stratification. Examples include the use of BRAF inhibitors in BRAF-mutant melanoma [35], the use of KIT inhibitors in gastrointestinal stromal tumors (GIST) harboring activating KIT mutations [36], application of EGFR inhibitors in non-small-cell lung cancer (NSCLC) with activating EGFR mutations [37], or the negative predictive value of $R A S$ mutations for EGFR antibodies in CRC [38]. However, tissue biopsies are invasive and bear the risk of complications [39], whereas liquid biopsy approaches are less invasive and thus suitable for repeated analyses. The use of tissue for cancer sequencing is limited by a variable content of tumor cellularity, and preservation techniques compromise the integrity of DNA usually extracted from formalin-fixed paraffin-embedded material [40]. While the tumor-derived DNA content and cfDNA fraction will also vary, blood-derived ctDNA can be freshly used at any time. In a blinded prospective study, the BRAF and KRAS mutation status in tissue and ctDNA showed a concordance rate of $96 \%$ with a sensitivity and specificity for ctDNA of 93 and $98 \%$, respectively [22] (table 2). In a different study assessing ctDNA genotyping using hybrid-capture sequencing in patients with stage I-IV NSCLC, ctDNA was detected with a sensitivity of $100 \%$ in stage II-IV patients and $50 \%$ in stage I patients, with a specificity of $96 \%$ [30]. In a retrospective study comparing ctDNA samples from patients with NSCLC, GIST, CRC, and melanoma, analyzed using 6-gene panel sequencing with paired tissue samples and a Taqman-derived assay [41], the sensitivity and specificity of ctDNA detection relative to tumor tissue was 79 and $100 \%$, respectively, with $96.8 \%$ concordance. These data suggest that ctDNA-based genotyping is feasible and competitive compared to tissue-based analysis.

Recently, it has become evident that cancers display a high level of clonal genetic heterogeneity between the primary and metastases, and even within specific lesions [42, 43]. While limited spatial coverage of a tissue biopsy might introduce a sampling bias, a liquid biopsy approach covering and integrating the genetic 'output' of all coexisting lesions should be able to depict the predominating genetic fingerprint of the disease within 1 blood sample (fig. 1B). Moreover, it has become increasingly evident that the clonal genetic composition of a cancer is a highly dynamic process, especially if cancer cells are faced with the selection pressure of a molecular targeted treatment. Repeated blood sampling is minimally invasive and allows dynamic genotyping of the disease. Depicting changes in the mutational landscape over time might allow to adapt the treatment accordingly. Examples include selection of secondary EGFR kinase domain mutations mediating resistance to EGFR kinase inhibitors [44], or selection of RAS-mutant clones in CRC receiving EGFR antibodies [45]. 


\section{Monitoring Treatment Response}

A growing body of data supports the concept that changes in the amount of ctDNA correlate with tumor burden and may thus be used for disease monitoring. The short half-life of ctDNA of less than $2 \mathrm{~h}$ represents a challenge for sample processing unless collection tubes including additives are used; however, on the other side, it allows real-time assessment of tumor activity and genotype. Studies in CRC, breast and ovarian cancer, melanoma, GIST, and lymphoma have shown that levels of ctDNA correlate with the clinical course of the disease in individual patients and can precede changes seen in imaging studies by weeks or months $[21,28,29$, 46-48]. Thus, ctDNA monitoring might allow early assessment of response and prediction of progression. In a study of 18 patients with stage II-IV CRC, mutations in 4 genes (PIK3CA, APC, TP53, and $K R A S$ ) were quantified in the ctDNA in serial plasma samples using BEAMing [21]. The median ctDNA levels decreased by $96.7 \%$ only $24 \mathrm{~h}$ after surgery, and correlated with the clinical course thereafter. In 30 patients with metastatic breast cancer receiving systemic therapy, a prospective trial assessed the levels of ctDNA harboring TP53 and PIK3CA mutations using amplicon sequencing and dPCR [49]. In this analysis, the levels of mutant ctDNA correlated with disease status as measured by CT. Analysis of ctDNA displayed superior sensitivity when compared to levels of CTCs and carcinoma antigen (CA) 15-3 (table 2), and predicted response to treatment as assessed by CT. In 17 patients with localized and metastatic NSCLC, a prospective study assessed ctDNA using hybrid-capture sequencing with barcoding [30]. The levels of ctDNA correlated with tumor volume and predicted radiographic responses. Importantly, the assay design allowed the detection of single nucleotide variants, rearrangements of $A L K, R O S 1$, and RET, insertions and deletions (indels), and copy number alterations. The detection limit of mutant allele fractions in ctDNA was $0.02 \%$. Of note, analysis of ctDNA depicted clonal heterogeneity in individual patients such as co-occurrence of ROS and ALK fusions in 1 individual patient.

\section{Clonal Heterogeneity and Treatment Resistance}

It has become impressively evident that therapeutic strategies and specific drugs are no longer specific for treatment of distinct entities but rather for particular molecular profiles across entities [50]. However, several additional layers of complexity aggravate simple 1-mutation/1-drug approaches. First, it is difficult to discriminate significant mutations and pathways from background and passenger mutations [51]. Second, the clonal genetic composition varies between patients, within 1 patient between lesions [42], and even within single lesions [43]. Finally, genetic composition is a highly dynamic process, especially if treatment leads to the selection of resistant subclones. In tissue, the analysis of the clonal composition of a tumor requires multiple single-region or single-cell samples $[42,52,53]$. Since ctDNA should be able to integrate DNA shed from different cancer lesions in 1 sample, it probably repre- sents the most accurate strategy to query clonal heterogeneity and to study changes in clonal composition over time (fig. 1B). Consequently, ctDNA analysis has detected cancer mutations that were missed in corresponding tissue $[45,54]$, and ctDNA allele frequency can inform about clonal and subclonal mutations [55]. Recently, it has been shown that hybrid-capture sequencing of ctDNA can depict changes in clonal composition over time in breast, ovarian, and lung cancer, and thus can inform about mutations associated with acquired drug resistance [56]. In practice, the aim of serial genotyping of ctDNA would be to query known genetic changes that mediate resistance to treatment and/or predict response to treatment. In chronic myeloid leukemia, tumor cells are easily accessible, and monitoring of emerging disease subclones harboring secondary mutations in $B C R-A B L$ that mediate resistance to ABL kinase inhibitors is routinely performed [57]. In solid tumors, ctDNA analysis might provide valuable information for dynamic treatment stratification. In lung adenocarcinoma, about half of the patients carry at least 1 driver mutation representing a rational target for therapeutic intervention [58]. Among those, activating EGFR mutations are predictive for response to EGFR inhibitors such as erlotinib and gefitinib [37]. Analysis of ctDNA has been demonstrated to detect EGFR exon 19 deletions and L858R mutations with a sensitivity of $82-87 \%$ and a specificity of $97-98 \%$ $[54,59]$, and thus might be a suitable alternative to tissue genotyping. Most patients receiving EGFR-inhibiting drugs will eventually experience disease progression within 2 years of treatment, and in $60 \%$ resistance to treatment is caused by selection of a disease clone harboring an EGFR T790M secondary mutation that blocks the access of the drug to the kinase [44]. EGFR T790M is predictive for response to osimertinib [60], and prescription requires a positive mutation test. In the phase I AURA study that assessed the safety, tolerability, and efficacy of osimertinib in patients with EGFR mutation-positive NSCLC who had progressed following prior therapy with an EGFR inhibitor, testing of ctDNA for T790M demonstrated a sensitivity of $70-81 \%$ with a specificity of $58-69 \%$ with tissue results as reference standard $[54,59]$. The inferior results compared to the detection of exon 19 deletions and L858R in ctDNA probably reflect a more pronounced clonal heterogeneity in the resistant situation. Of note, plasma T790M-positive patients had a similar outcome to tissue T790M-positive patients. Thus, a T790M-positive plasma genotype may obviate the need for a biopsy. In contrast, plasma T790M-negative patients would require confirmatory tissue biopsy, as plasma-negative and tumor T790Mpositive patients had a favorable outcome. Of note, plasma T790Mpositive and tissue-negative patients had an outcome only slightly superior to double-negative patients, again reflecting the notion that ctDNA might detect a minor subclone [54].

Patients with CRC and KRAS mutations do not benefit from anti-EGFR therapy [61-63], and mutations in BRAF, NRAS, and PIK3CA may similarly confer resistance to such treatments [6466]. In patients with metastatic RAS wild-type CRC, the acquisition of RAS and BRAF mutations in ctDNA was associated with and often preceded acquired treatment resistance [20, 38, 45, 67, 68]. Importantly, different mutations in ctDNA can coexist in individ- 
ual patients, probably reflecting clonal divergence under treatment-induced selection pressure [20, 67, 68]. Mutant clones can decline upon withdrawal of EGFR-specific antibodies, and a treatment re-challenge may lead to responses in some cases [45]. These observations demonstrate a remarkable clonal plasticity of cancer, which can be tracked using ctDNA analyses, allowing dynamic treatment stratification and pulsatile treatment strategies.

\section{Early Detection and Minimal Residual Disease}

Early detection of cancer allows curative intervention and thus might improve survival. Detection rates of ctDNA differ with entity and tumor stage at the time of sampling [20]. In a study of breast, colon, pancreatic, and gastroesophageal cancer, the detection rates of ctDNA varied between 49 and $78 \%$ in patients with localized disease, and 86 and $100 \%$ in patients with metastatic disease [20]. Of all patients with stage I cancer of any type, $47 \%$ were ctDNA-positive versus $82 \%$ with stage IV. In a different study, $32 \%$ of stage I/II melanoma versus $39 \%$ of stage III/IV patients were ctDNA-positive [47]. Thus, ctDNA detection rates are determined by biology (type of cancer, site, proliferation rate, vascularization), stage, pre-analytical factors including collection, processing, and extraction of samples and the volume of plasma used for ctDNA purification, and, finally, analytical factors and conditions including the sensitivity and specificity of the assay used. In early-stage breast cancer, detection of known mutations in ctDNA by dPCR showed a sensitivity of $93.3 \%$ [69]. In a study using hybrid-capture sequencing, ctDNA analysis in single patients with localized NSCLC after radiotherapy or chemoradiotherapy successfully distinguished between residual disease and treatment-related imaging changes [30], and adding integrated digital error suppression (iDES) allowed the detection of ctDNA even in stage I NSCLC in 3 out of 3 cases [34]. In practice, early-stage cancer might be successfully detected by sensitive assays such as APCR and the targeting of known or recurrent hot-spot mutations. In contrast, while ultrasensitive targeted sequencing or even sequencing of the entire genome from ctDNA will allow detection of any cancer mutation, it will at the same time require extensive bioinformatic analyses ('data polishing') to achieve a high diagnostic specificity, especially in early-stage cancer. Still, the presence of a low-level 'cancer' mutation such as TP53 or RAS in cfDNA might not necessarily indicate the presence of cancer $[34,70,71]$, and the management of ctDNA-positive patients with negative imaging results would remain to be evaluated in prospective studies.

During follow-up of patients in complete remission, ctDNA analysis might allow minimal residual disease (MRD) detection, and thus might complement the information provided by imaging studies. Several studies have shown that a rise in ctDNA can precede cancer relapse by months [28, 34, 72]. Assays detecting tumor-specific translocations might offer a particular high sensitivity and specificity [73], and a small study in neuroblastoma suggests that MRD measurement of structural changes in ctDNA might not only allow prediction of relapse but might also be of prognostic sig- nificance [74]. However, prospective data demonstrating the significance of ctDNA analyses in identifying patients who are at risk of relapse after treatment of localized cancer, or in detecting a relapse early during follow-up, are missing, and thus liquid biopsy assays cannot complement regular follow-up studies at this time. In a retrospective study of 18 patients who underwent surgery for CRC with curative intent, ctDNA positivity at first follow-up after resection was highly predictive for relapse (relapse in 16/20 cases) whereas none of the 4 subjects negative for ctDNA relapsed [21]. Of note, the reliable identification of patients at risk of relapse would allow interventions, such as the stratification of adjuvant treatment. Thus, unnecessary treatment and toxicities would be avoided. In addition, extensive imaging for routine monitoring and follow-up might be cut down and adapted to individual risk.

A recently published prospective trial evaluated multitarget stool DNA testing for CRC screening. In 9,989 participants with an average risk for CRC, DNA testing had a higher sensitivity for detecting CRC but produced more false-positive results compared to a standard hemoglobin immunoassay [75]. The number needed to screen to detect 1 cancer was 154 with colonoscopy, 166 with DNA testing, and 208 with the hemoglobin immunoassay, and the effects on outcomes and costs were not examined. Clinical testing of a ctDNA assay for cancer screening would have to follow a similar study design. The significance of detecting ctDNA for early detection and screening is unclear at this time since prospective data are missing.

\section{Prognostic Stratification}

The presence of CTCs constitutes a strong independent prognostic factor for overall survival (OS) in small-cell lung cancer [76], breast cancer [77, 78], CRC [79], prostate cancer [80], and in neuroendocrine tumors [81]. Of note, changing treatment in patients with CTC-positive metastatic breast cancer did not improve outcome [77]; hence the feature of shedding CTCs or ctDNA might well be an independent biologic property of a cancer correlated with clinical behavior and prognosis. A number of reports support the concept that ctDNA levels provide prognostic information. In patients with stage I-IV CRC, the detection of KRAS mutations in ctDNA predicted recurrence-free survival (RFS) and OS [82]. Later studies confirmed the predictive value of ctDNA levels for RFS and OS [20,21, 48]. In addition, these studies indicated that the amount of ctDNA might be independent of established prognostic factors (age, ECOG performance status, and CEA) $[20,21]$, and that the slope of ctDNA after initiation of treatment adds prognostic information [48]. In a prospective study with 230 stage II CRC patients, subjects with positive ctDNA at first follow-up had a 3 -year RFS of $0 \%$ in contrast to $90 \%$ in the ctDNA-negative patients [83], suggesting that ctDNA might in the future be used to stratify for adjuvant treatment. In stage IV BRAF V600 mutation-positive melanoma, the detection of ctDNA indicated inferior progression-free survival and OS [84]. In metastatic breast cancer, quantiles of ctDNA but not CA 
15-3 levels were highly predictive for OS [49]. In addition, the kinetics of mutant clones as depicted in ctDNA can be prognostic. In stage IV CRC patients receiving chemotherapy and the EGFR-specific antibody cetuximab, a 45-205× ctDNA 'explosion' was predictive for fast disease progression and death [67]. Thus, shedding of ctDNA seems to reflect an aggressive cancer biology and the dynamics of clonal expansion and progression. In fact, shedding of tumor content might determine the progression of cancer. Data from a melanoma mouse model suggest that microvesicles containing ctDNA and RNA might direct metastatic behavior of a cancer [85]

\section{Conclusion}

At present, the routine clinical use of ctDNA analysis is limited to commercially available (cobas ${ }^{\circledR}$ EGFR, Roche Molecular Systems, Pleasanton, CA, USA; therascreen ${ }^{\circledR}$ EGFR, Qiagen, Hilden, Germany) or validated non-commercial tests approved by the US Food and Drug Administration (FDA) and the European Medicines Agency (EMA) to select patients with NSCLC for the appropriate EGFR-directed therapy. However, in the event of a negative ctDNA analysis, a tissue biopsy will be necessary. Other tests and applications will follow, and, if validated in prospective studies, will enter routine diagnostic use. Testing for ctDNA will be a unique tool to monitor responses and to allow non-invasive serial genotyping. The emergence of mutant clones might be detected months prior to radiographic progression. This will allow early identification of resistance and inform about the appropriate next line of treatment.
Still, many applications for liquid biopsy technologies will be investigational, and many questions remain open. To date, mutationbased biomarkers in most cases are not informative for tumor type. Thus, liquid biopsy approaches will not replace tissue-based diagnostics at baseline. In addition, the absolute sensitivity and specificity of ctDNA detection might challenge the screening and early detection of cancer, and even in advanced-stage cancer it is currently unclear whether all tumor manifestations equally contribute to ctDNA composition. To implement liquid biopsy approaches into clinical routine, the next important step will be to compare ctDNA-guided treatment stratification with standard of care in prospective randomized studies.

\section{Acknowledgement}

The author would like to thank all members of the Plasma Laboratory Freiburg as well as J. Duyster, Department of Hematology, Oncology and Stem Cell Transplantation, Medical Center University of Freiburg for their support. He would like to thank U. Breschke (Ketchum Pleon, Dresden) for providing the images used in figure 1. The author would also like to acknowledge the support of the University of Freiburg Medical Faculty, the Comprehensive Cancer Centre Freiburg (CCCF), and the German Cancer Consortium (DKTK), and the Bundesministerium für Bildung und Forschung (BMBF; grant no. 71; to N.v.B.) and Novartis Germany for research support (to N.v.B.).

\section{Disclosure Statement}

N.v.B. received honoraria from Novartis and BMS and research funding from Novartis.

\section{References}

1 Vogelstein B, Papadopoulos N, Velculescu VE, Zhou S, Diaz LA Jr, Kinzler KW: Cancer genome landscapes. Science 2013;339:1546-1558.

2 Hanahan D, Weinberg RA: Hallmarks of cancer: the next generation. Cell 2011;144:646-674.

3 Roychowdhury S, Iyer MK, Robinson DR, Lonigro RJ, Wu YM, Cao X, Kalyana-Sundaram S, Sam L, Balbin OA, Quist MJ, Barrette T, Everett J, Siddiqui J, Kunju LP, Navone N, Araujo JC, Troncoso P, Logothetis CJ, Innis JW, Smith DC, Lao CD, Kim SY, Roberts JS, Gruber SB, Pienta KJ, Talpaz M, Chinnaiyan AM: Personalized oncology through integrative high-throughput sequencing: a pilot study. Sci Transl Med 2011;3: 111 ra121.

4 Gambhir SS, Czernin J, Schwimmer J, Silverman DH, Coleman RE, Phelps ME: A tabulated summary of the FDG PET literature. J Nucl Med 2001;42:1S-93S.

5 Horton KM, Abrams RA, Fishman EK: Spiral CT of colon cancer: imaging features and role in management. Radiographics 2000;20:419-430.

6 Wolchok JD, Hoos A, O'Day S, Weber JS, Hamid O, Lebbe C, Maio M, Binder M, Bohnsack O, Nichol G, Humphrey R, Hodi FS: Guidelines for the evaluation of immune therapy activity in solid tumors: immunerelated response criteria. Clin Cancer Res 2009; 15: 7412-7420.
7 Bhavsar T, McCue P, Birbe R: Molecular diagnosis of prostate cancer: are we up to age? Semin Oncol 2013; 40:259-275.

8 Fletcher RH: Carcinoembryonic antigen. Ann Intern Med 1986;104:66-73.

9 Vereecken P, Cornelis F, Van Baren N, Vandersleyen V, Baurain JF: A synopsis of serum biomarkers in cutaneous melanoma patients. Dermatol Res Pract 2012; 2012:260643.

10 Gebhardt C, Lichtenberger R, Utikal J: Biomarker value and pitfalls of serum S100B in the follow-up of high-risk melanoma patients. J Dtsch Dermatol Ges 2016;14:158-164.

11 Fleischhacker M, Schmidt B: Circulating nucleic acids (CNAs) and cancer - a survey. Biochim Biophys Acta 2007;1775:181-232.

12 Mandel P, Metais P: Les acides nucléiques du plasma sanguin chez l'homme. C R Seances Soc Biol Fil 1948; 142:241-243.

13 Jing RR, Wang HM, Cui M, Fang MK, Qiu XJ, Wu XH, Qi J, Wang YG, Zhang LR, Zhu JH, Ju SQ: A sensitive method to quantify human cell-free circulating DNA in blood: relevance to myocardial infarction screening. Clin Biochem 2011;44:1074-1079.

14 Beiter T, Fragasso A, Hudemann J, Niess AM, Simon P: Short-term treadmill running as a model for studying cell-free DNA kinetics in vivo. Clin Chem 2011;57: 633-636.
15 Leon SA, Shapiro B, Sklaroff DM, Yaros MJ: Free DNA in the serum of cancer patients and the effect of therapy. Cancer Res 1977;37:646-650.

16 Lo YM, Chiu RW: Genomic analysis of fetal nucleic acids in maternal blood. Annu Rev Genomics Hum Genet 2012;13:285-306.

17 Norton ME, Jacobsson B, Swamy GK, Laurent LC Ranzini AC, Brar H, Tomlinson MW, Pereira L, Spitz JL, Hollemon D, Cuckle H, Musci TJ, Wapner RJ: Cellfree DNA analysis for noninvasive examination of trisomy. N Engl J Med 2015;372:1589-1597.

18 Stroun M, Lyautey J, Lederrey C, Olson-Sand A, Anker P: About the possible origin and mechanism of circulating DNA apoptosis and active DNA release. Clin Chim Acta 2001;313:139-142.

19 Jahr S, Hentze H, Englisch S, Hardt D, Fackelmayer FO, Hesch RD, Knippers R: DNA fragments in the blood plasma of cancer patients: quantitations and evidence for their origin from apoptotic and necrotic cells. Cancer Res 2001;61:1659-1665.

20 Bettegowda C, Sausen M, Leary RJ, Kinde I, Wang Y, Agrawal N, Bartlett BR, Wang H, Luber B, Alani RM, Antonarakis ES, Azad NS, Bardelli A, Brem H, Cameron JL, Lee CC, Fecher LA, Gallia GL, Gibbs P, Le D, Giuntoli RL, Goggins M, Hogarty MD, Holdhoff M, Hong SM, Jiao Y, Juhl HH, Kim JJ, Siravegna G, Laheru DA, Lauricella C, Lim M, Lipson EJ, Marie SK, 
Netto GJ, Oliner KS, Olivi A, Olsson L, Riggins GJ, Sartore-Bianchi A, Schmidt K, Shih l M, Oba-Shinjo SM, Siena S, Theodorescu D, Tie J, Harkins TT, Veronese $\mathrm{S}$, Wang TL, Weingart JD, Wolfgang $\mathrm{CL}$, Wood LD, Xing D, Hruban RH, Wu J, Allen PJ, Schmidt CM, Choti MA, Velculescu VE, Kinzler KW, Vogelstein B, Papadopoulos N, Diaz LA Jr: Detection of circulating tumor DNA in early- and late-stage human malignancies. Sci Transl Med 2014;6:224ra224.

21 Diehl F, Schmidt K, Choti MA, Romans K, Goodman S, Li M, Thornton K, Agrawal N, Sokoll L, Szabo SA, Kinzler KW, Vogelstein B, Diaz LA Jr: Circulating mutant DNA to assess tumor dynamics. Nat Med 2008; 14 : 985-990.

22 Thierry AR, Mouliere F, El Messaoudi S, Mollevi C, Lopez-Crapez E, Rolet F, Gillet B, Gongora C, Dechelotte P, Robert B, Del Rio M, Lamy PJ, Bibeau F, Nouaille M, Loriot V, Jarrousse AS, Molina F, Mathonnet M, Pezet D, Ychou M: Clinical validation of the detection of KRAS and BRAF mutations from circulating tumor DNA. Nat Med 2014;20:430-435.

23 Diaz LA Jr, Bardelli A: Liquid biopsies: genotyping circulating tumor DNA. J Clin Oncol 2014;32:579-586.

24 Maheswaran S, Sequist LV, Nagrath S, Ulkus L, Brannigan B, Collura CV, Inserra E, Diederichs S, Iafrate AJ, Bell DW, Digumarthy S, Muzikansky A, Irimia D, Settleman J, Tompkins RG, Lynch TJ, Toner M, Haber DA: Detection of mutations in EGFR in circulating lung-cancer cells. N Engl J Med 2008;359:366-377.

25 Heitzer E, Auer M, Gasch C, Pichler M, Ulz P, Hoffmann EM, Lax S, Waldispuehl-Geigl J, Mauermann O, Lackner C, Hofler G, Eisner F, Sill H, Samonigg H, Pantel K, Riethdorf S, Bauernhofer T, Geigl JB, Speicher MR: Complex tumor genomes inferred from single circulating tumor cells by array-CGH and nextgeneration sequencing. Cancer Res 2013;73:2965-2975.

26 Vogelstein B, Kinzler KW: Digital PCR. Proc Natl Acad Sci U S A 1999;96:9236-9241.

27 Diehl F, Li M, He Y, Kinzler KW, Vogelstein B, Dressman D: Beaming: single-molecule PCR on microparticles in water-in-oil emulsions. Nat Methods 2006;3: 551-559.

28 Maier J, Lange T, Kerle I, Specht K, Bruegel M, Wickenhauser C, Jost P, Niederwieser D, Peschel C, Duyster J, von Bubnoff N: Detection of mutant free circulating tumor DNA in the plasma of patients with gastrointestinal stromal tumor harboring activating mutations of CKIT or PDGFRA. Clin Cancer Res 2013;19:4854-4867.

29 Forshew T, Murtaza M, Parkinson C, Gale D, Tsui DW, Kaper F, Dawson SJ, Piskorz AM, Jimenez-Linan M, Bentley D, Hadfield J, May AP, Caldas C, Brenton JD, Rosenfeld N: Noninvasive identification and monitoring of cancer mutations by targeted deep sequencing of plasma DNA. Sci Transl Med 2012;4:136ra168.

30 Newman AM, Bratman SV, To J, Wynne JF, Eclov NC, Modlin LA, Liu CL, Neal JW, Wakelee HA, Merritt RE, Shrager JB, Loo BW Jr, Alizadeh AA, Diehn M: An ultrasensitive method for quantitating circulating tumor DNA with broad patient coverage. Nat Med 2014;20: 548-554.

31 Taly V, Pekin D, Benhaim L, Kotsopoulos SK, Le Corre D, Li X, Atochin I, Link DR, Griffiths AD, Pallier K, Blons H, Bouche O, Landi B, Hutchison JB, LaurentPuig P: Multiplex picodroplet digital PCR to detect KRAS mutations in circulating DNA from the plasma of colorectal cancer patients. Clin Chem 2013;59: $1722-1731$.

32 Oxnard GR, Paweletz CP, Kuang Y, Mach SL, O'Connell A, Messineo MM, Luke JJ, Butaney M, Kirschmeier P, Jackman DM, Janne PA: Noninvasive detection of response and resistance in EGFR-mutant lung cancer using quantitative next-generation genotyping of cell-free plasma DNA. Clin Cancer Res 2014; 20:1698-1705.
33 Kinde I, Wu J, Papadopoulos N, Kinzler KW, Vogelstein B: Detection and quantification of rare mutations with massively parallel sequencing. Proc Natl Acad Sci U S A 2011;108:9530-9535.

34 Newman AM, Lovejoy AF, Klass DM, Kurtz DM, Chabon JJ, Scherer F, Stehr H, Liu CL, Bratman SV, Say C, Zhou L, Carter JN, West RB, Sledge GW Jr, Shrager JB, Loo BW Jr, Neal JW, Wakelee HA, Diehn M, Alizadeh AA: Integrated digital error suppression for improved detection of circulating tumor DNA. Nat Biotechnol 2016;34:547-555.

35 Robert C, Karaszewska B, Schachter J, Rutkowski P, Mackiewicz A, Stroiakovski D, Lichinitser M, Dummer R, Grange F, Mortier L, Chiarion-Sileni V, Drucis K, Krajsova I, Hauschild A, Lorigan P, Wolter P, Long GV, Flaherty K, Nathan P, Ribas A, Martin AM, Sun P, Crist W, Legos J, Rubin SD, Little SM, Schadendorf D: Improved overall survival in melanoma with combined dabrafenib and trametinib. N Engl J Med 2015;372: 30-39.

36 Verweij J, Casali PG, Zalcberg J, LeCesne A, Reichardt P, Blay JY, Issels R, van Oosterom A, Hogendoorn PC, van Glabbeke M, Bertulli R, Judson I: Progression-free survival in gastrointestinal stromal tumours with highdose imatinib: randomised trial. Lancet 2004;364: 1127-1134.

37 Maemondo M, Inoue A, Kobayashi K, Sugawara S, Oizumi S, Isobe $\mathrm{H}$, Gemma A, Harada M, Yoshizawa $\mathrm{H}$, Kinoshita I, Fujita Y, Okinaga S, Hirano H, Yoshimori K, Harada T, Ogura T, Ando M, Miyazawa H, Tanaka T, Saijo Y, Hagiwara K, Morita S, Nukiwa T; NorthEast Japan Study Group: Gefitinib or chemotherapy for non-small-cell lung cancer with mutated EGFR. N Engl J Med 2010;362:2380-2388.

38 Misale S, Yaeger R, Hobor S, Scala E, Janakiraman M, Liska D, Valtorta E, Schiavo R, Buscarino M, Siravegna G, Bencardino K, Cercek A, Chen CT, Veronese S, Zanon C, Sartore-Bianchi A, Gambacorta M, Gallicchio M, Vakiani E, Boscaro V, Medico E, Weiser M, Siena S, Di Nicolantonio F, Solit D, Bardelli A: Emergence of KRAS mutations and acquired resistance to anti-EGFR therapy in colorectal cancer. Nature 2012;486:532-536.

39 Overman MJ, Modak J, Kopetz S, Murthy R, Yao JC, Hicks ME, Abbruzzese JL, Tam AL: Use of research biopsies in clinical trials: are risks and benefits adequately discussed? J Clin Oncol 2013;31:17-22.

40 Gilbert MT, Haselkorn T, Bunce M, Sanchez JJ, Lucas SB, Jewell LD, Van Marck E, Worobey M: The isolation of nucleic acids from fixed, paraffin-embedded tissues-which methods are useful when? PLoS One 2007;2:e537.

41 Malapelle U, Mayo de-Las-Casas C, Rocco D, Garzon M, Pisapia P, Jordana-Ariza N, Russo M, Sgariglia R, De Luca C, Pepe F, Martinez-Bueno A, Morales-Espinosa D, Gonzalez-Cao M, Karachaliou N, Viteri Ramirez S, Bellevicine C, Molina-Vila MA, Rosell R, Troncone G: Development of a gene panel for next-generation sequencing of clinically relevant mutations in cell-free DNA from cancer patients. Br J Cancer 2017; 116:802-810.

42 Gerlinger M, Rowan AJ, Horswell S, Larkin J, Endesfelder D, Gronroos E, M artinez P, Matthews N, Stewart A, Tarpey P, Varela I, Phillimore B, Begum S, McDonald NQ, Butler A, Jones D, Raine K, Latimer C, Santos CR, Nohadani M, Eklund AC, Spencer-Dene B, Clark G, Pickering L, Stamp G, Gore M, Szallasi Z, Downward J, Futreal PA, Swanton C: Intratumor heterogeneity and branched evolution revealed by multiregion sequencing. N Engl J Med 2012;366:883-892.

43 Xu X, Hou Y, Yin X, Bao L, Tang A, Song L, Li F, Tsang S, Wu K, Wu H, He W, Zeng L, Xing M, Wu R, Jiang H, Liu X, Cao D, Guo G, Hu X, Gui Y, Li Z, Xie W, Sun X, Shi M, Cai Z, Wang B, Zhong M, Li J, Lu Z, Gu N, Zhang X, Goodman L, Bolund L, Wang J, Yang H,
Kristiansen K, Dean M, Li Y, Wang J: Single-cell exome sequencing reveals single-nucleotide mutation characteristics of a kidney tumor. Cell 2012;148:886-895.

44 Kobayashi S, Boggon TJ, Dayaram T, Janne PA, Kocher O, Meyerson M, Johnson BE, Eck MJ, Tenen DG, Halmos B: EGFR mutation and resistance of nonsmall-cell lung cancer to gefitinib. N Engl J Med 2005; 352:786-792.

45 Siravegna G, Mussolin B, Buscarino M, Corti G, Cassingena A, Crisafulli G, Ponzetti A, Cremolini C, Amatu A, Lauricella C, Lamba S, Hobor S, Avallone A, Valtorta E, Rospo G, Medico E, Motta V, Antoniotti C Tatangelo F, Bellosillo B, Veronese S, Budillon A, Montagut C, Racca P, Marsoni S, Falcone A, Corcoran RB, Di Nicolantonio F, Loupakis F, Siena S, SartoreBianchi A, Bardelli A: Clonal evolution and resistance to EGFR blockade in the blood of colorectal cancer patients. Nat Med 2015;21:795-801

46 Dawson SJ, Rosenfeld N, Caldas C: Circulating tumo DNA to monitor metastatic breast cancer. N Engl J Med 2013;369:93-94.

47 Shinozaki M, O'Day SJ, Kitago M, Amersi F, Kuo C, Kim J, Wang HJ, Hoon DS: Utility of circulating B-RAF DNA mutation in serum for monitoring melanoma patients receiving biochemotherapy. Clin Cancer Res 2007;13:2068-2074.

48 Garlan F, Laurent-Puig P, Sefrioui D, Siauve N, Didelot A, Sarafan-Vasseur N, Michel P, Perkins G, Mulot C, Blons H, Taieb J, Di Fiore F, Taly V, Zaanan A: Early evaluation of circulating tumor DNA as marker of therapeutic efficacy in metastatic colorectal cancer patients (PLACOL study). Clin Cancer Res 2017; Epub ahead of print.

49 Dawson SJ, Tsui DW, Murtaza M, Biggs H, Rueda OM, Chin SF, Dunning MJ, Gale D, Forshew T, MahlerAraujo B, Rajan S, Humphray S, Becq J, Halsall D, Wallis M, Bentley D, Caldas C, Rosenfeld N: Analysis of circulating tumor DNA to monitor metastatic breast cancer. N Engl J Med 2013;368:1199-1209.

50 Hoadley KA, Yau C, Wolf DM, Cherniack AD, Tamborero D, Ng S, Leiserson MD, Niu B, McLellan MD, Uzunangelov V, Zhang J, Kandoth C, Akbani R, Shen H, Omberg L, Chu A, Margolin AA, Van't Veer LJ, LopezBigas N, Laird PW, Raphael BJ, Ding L, Robertson AG, Byers LA, Mills GB, Weinstein JN, Van Waes C, Chen Z, Collisson EA; Cancer Genome Atlas Research Network, Benz CC, Perou CM, Stuart JM: Multiplatform analysis of 12 cancer types reveals molecular classification within and across tissues of origin. Cell 2014;158:929-944.

51 Lawrence MS, Stojanov P, Polak P, Kryukov GV, Cibulskis K, Sivachenko A, Carter SL, Stewart C, Mermel CH, Roberts SA, Kiezun A, Hammerman PS, McKenna A, Drier Y, Zou L, Ramos AH, Pugh TJ, Stransky N, Helman E, Kim J, Sougnez C, Ambrogio L, Nickerson E, Shefler E, Cortes ML, Auclair D, Saksena G, Voet D, Noble M, DiCara D, Lin P, Lichtenstein L, Heiman DI, Fennell T, Imielinski M, Hernandez B, Hodis E, Baca S, Dulak AM, Lohr J, Landau DA, Wu CJ, Melendez-Zajgla J, Hidalgo-Miranda A, Koren A, McCarroll SA, Mora J, Lee RS, Crompton B, Onofrio R, Parkin M, Winckler W, Ardlie K, Gabriel SB, Roberts CW, Biegel JA, Stegmaier K, Bass AJ, Garraway LA, Meyerson M, Golub TR, Gordenin DA, Sunyaev S, Lander ES, Getz G: Mutational heterogeneity in cancer and the search for new cancer-associated genes. Nature 2013;499:214-218.

52 Wang Y, Waters J, Leung ML, Unruh A, Roh W, Shi X, Chen K, Scheet P, Vattathil S, Liang H, Multani A, Zhang H, Zhao R, Michor F, Meric-Bernstam F, Navin NE: Clonal evolution in breast cancer revealed by single nucleus genome sequencing. Nature 2014;512: 155-160.

53 Swanton C, Govindan R: Clinical implications of genomic discoveries in lung cancer. $\mathrm{N}$ Engl J Med 2016;374:1864-1873 
54 Oxnard GR, Thress KS, Alden RS, Lawrance R, Paweletz CP, Cantarini M, Yang JC, Barrett JC, Janne PA: Association between plasma genotyping and outcomes of treatment with osimertinib (AZD9291) in advanced non-small-cell lung cancer. J Clin Oncol 2016;34:3375-3382.

55 Jamal-Hanjani M, Wilson GA, Horswell S, Mitter R, Sakarya O, Constantin T, Salari R, Kirkizlar E, Sigurjonsson S, Pelham R, Kareht S, Zimmermann B, Swanton C: Detection of ubiquitous and heterogeneous mutations in cell-free DNA from patients with early-stage nonsmall-cell lung cancer. Ann Oncol 2016;27:862-867.

56 Murtaza M, Dawson SJ, Tsui DW, Gale D, Forshew T, Piskorz AM, Parkinson C, Chin SF, Kingsbury Z, Wong AS, Marass F, Humphray S, Hadfield J, Bentley D, Chin TM, Brenton JD, Caldas C, Rosenfeld N: Non-invasive analysis of acquired resistance to cancer therapy by sequencing of plasma DNA. Nature 2013;497:108-112.

57 Von Bubnoff N, Duyster J: Chronic myelogenous leukemia: treatment and monitoring. Dtsch Arztebl Int 2010;107:114-121.

58 Li T, Kung HJ, Mack PC, Gandara DR: Genotyping and genomic profiling of non-small-cell lung cancer: implications for current and future therapies. J Clin Oncol 2013;31:1039-1049.

59 Thress KS, Brant R, Carr TH, Dearden S, Jenkins S, Brown H, Hammett T, Cantarini M, Barrett JC: EGFR mutation detection in ctDNA from NSCLC patient plasma: a cross-platform comparison of leading technologies to support the clinical development of AZD9291. Lung Cancer 2015;90:509-515.

60 Janne PA, Yang JC, Kim DW, Planchard D, Ohe Y, Ramalingam SS, Ahn MJ, Kim SW, Su WC, Horn L, Haggstrom D, Felip E, Kim JH, Frewer P, Cantarini M, Brown KH, Dickinson PA, Ghiorghiu S, Ranson M: AZD9291 in EGFR inhibitor-resistant non-small-cell lung cancer. N Engl J Med 2015;372:1689-1699.

61 Maughan TS, Adams RA, Smith CG, Meade AM, Seymour MT, Wilson RH, Idziaszczyk S, Harris R, Fisher D, Kenny SL, Kay E, Mitchell JK, Madi A, Jasani B, James MD, Bridgewater J, Kennedy MJ, Claes B, Lambrechts D, Kaplan R, Cheadle JP; MRC COIN Trial Investigators: Addition of cetuximab to oxaliplatinbased first-line combination chemotherapy for treatment of advanced colorectal cancer: results of the randomised phase 3 MRC COIN trial. Lancet 2011;377: 2103-2114.

62 Price TJ, Hardingham JE, Lee CK, Weickhardt A, Townsend AR, Wrin JW, Chua A, Shivasami A, Cummins MM, Murone C, Tebbutt NC: Impact of KRAS and BRAF gene mutation status on outcomes from the phase III AGITG MAX trial of capecitabine alone or in combination with bevacizumab and mitomycin in advanced colorectal cancer. J Clin Oncol 2011;29:26752682.

63 Van Cutsem E, Kohne CH, Lang I, Folprecht G, Nowacki MP, Cascinu S, Shchepotin I, Maurel J, Cunningham D, Tejpar S, Schlichting M, Zubel A, Celik I, Rougier P, Ciardiello F: Cetuximab plus irinotecan, fluorouracil, and leucovorin as first-line treatment for metastatic colorectal cancer: updated analysis of overall survival according to tumor KRAS and BRAF mutation status. J Clin Oncol 2011;29:2011-2019.

64 Di Nicolantonio F, Martini M, Molinari F, Sartore-Bianchi A, Arena S, Saletti P, De Dosso S, Mazzucchelli L, Frattini M, Siena S, Bardelli A: Wild-type BRAF is required for response to panitumumab or cetuximab in metastatic colorectal cancer. J Clin Oncol 2008;26: 5705-5712.
65 Douillard JY, Oliner KS, Siena S, Tabernero J, Burkes R, Barugel M, Humblet Y, Bodoky G, Cunningham D, Jassem J, Rivera F, Kocakova I, Ruff P, BlasinskaMorawiec M, Smakal M, Canon JL, Rother M, Williams R, Rong A, Wiezorek J, Sidhu R, Patterson SD: Panitumumab-FOLFOX4 treatment and RAS mutations in colorectal cancer. N Engl J Med 2013;369: 1023-1034.

66 Bardelli A, Siena S: Molecular mechanisms of resistance to cetuximab and panitumumab in colorectal cancer. J Clin Oncol 2010;28:1254-1261.

67 Toledo RA, Cubillo A, Vega E, Garralda E, Alvarez R, de la Varga LU, Pascual JR, Sanchez G, Sarno F, Prieto SH, Perea S, Lopez-Casas PP, Lopez-Rios F, Hidalgo M: Clinical validation of prospective liquid biopsy monitoring in patients with wild-type RAS metastatic colorectal cancer treated with FOLFIRI-cetuximab. Oncotarget 2017;8:35289-35300.

68 Diaz LA Jr, Williams RT, Wu J, Kinde I, Hecht JR, Berlin J, Allen B, Bozic I, Reiter JG, Nowak MA, Kinzler KW, Oliner KS, Vogelstein B: The molecular evolution of acquired resistance to targeted EGFR blockade in colorectal cancers. Nature 2012;486:537-540.

69 Beaver JA, Jelovac D, Balukrishna S, Cochran RL, Croessmann S, Zabransky DJ, Wong HY, Valda Toro P, Cidado J, Blair BG, Chu D, Burns T, Higgins MJ, Stearns V, Jacobs L, Habibi M, Lange J, Hurley PJ, Lauring J, VanDenBerg DA, Kessler J, Jeter S, Samuels ML, Maar D, Cope L, Cimino-Mathews A, Argani P, Wolff AC, Park BH: Detection of cancer DNA in plasma of patients with early-stage breast cancer. Clin Cancer Res 2014;20:2643-2650.

70 Martincorena I, Roshan A, Gerstung M, Ellis P, Van Loo P, McLaren S, Wedge DC, Fullam A, Alexandrov LB, Tubio JM, Stebbings L, Menzies A, Widaa S, Stratton MR, Jones PH, Campbell PJ: Tumor evolution. High burden and pervasive positive selection of somatic mutations in normal human skin. Science 2015; 348:880-886.

71 Genovese G, Kahler AK, Handsaker RE, Lindberg J, Rose SA, Bakhoum SF, Chambert K, Mick E, Neale BM, Fromer M, Purcell SM, Svantesson O, Landen M, Hoglund M, Lehmann S, Gabriel SB, Moran JL, Lander ES, Sullivan PF, Sklar P, Gronberg H, Hultman CM, McCarroll SA: Clonal hematopoiesis and blood-cancer risk inferred from blood DNA sequence. $\mathrm{N}$ Engl J Med 2014;371:2477-2487.

72 Scherer F, Kurtz DM, Newman AM, Stehr H, Craig AF, Esfahani MS, Lovejoy AF, Chabon JJ, Klass DM, Liu CL, Zhou L, Glover C, Visser BC, Poultsides GA, Advani RH, Maeda LS, Gupta NK, Levy R, Ohgami RS, Kunder CA, Diehn M, Alizadeh AA: Distinct biological subtypes and patterns of genome evolution in lymphoma revealed by circulating tumor DNA. Sci Transl Med 2016;8:364ra155.

73 Leary RJ, Kinde I, Diehl F, Schmidt K, Clouser C, Duncan C, Antipova A, Lee C, McKernan K, De La Vega FM, Kinzler KW, Vogelstein B, Diaz LA Jr, Velculescu VE: Development of personalized tumor biomarkers using massively parallel sequencing. Sci Transl Med 2010;2:20ra14.

74 Sausen M, Leary RJ, Jones S, Wu J, Reynolds CP, Liu X, Blackford A, Parmigiani G, Diaz LA Jr, Papadopoulos N, Vogelstein B, Kinzler KW, Velculescu VE, Hogarty MD: Integrated genomic analyses identify ARID1A and ARID1B alterations in the childhood cancer neuroblastoma. Nat Genet 2013;45:12-17.

75 Imperiale TF, Ransohoff DF, Itzkowitz SH: Multitarget stool DNA testing for colorectal-cancer screening. N Engl J Med 2014;371:187-188.
76 Hou JM, Krebs MG, Lancashire L, Sloane R, Backen A, Swain RK, Priest LJ, Greystoke A, Zhou C, Morris K, Ward T, Blackhall FH, Dive C: Clinical significance and molecular characteristics of circulating tumor cells and circulating tumor microemboli in patients with small-cell lung cancer. J Clin Oncol 2012;30:525-532.

77 Smerage JB, Barlow WE, Hortobagyi GN, Winer EP, Leyland-Jones B, Srkalovic G, Tejwani S, Schott AF, O’Rourke MA, Lew DL, Doyle GV, Gralow JR, Livingston RB, Hayes DF: Circulating tumor cells and response to chemotherapy in metastatic breast cancer: SWOG S0500. J Clin Oncol 2014;32:3483-3489.

78 Cristofanilli M, Budd GT, Ellis MJ, Stopeck A, Matera J, Miller MC, Reuben JM, Doyle GV, Allard WJ, Terstappen LW, Hayes DF: Circulating tumor cells, disease progression, and survival in metastatic breast cancer. N Engl J Med 2004;351:781-791.

79 Cohen SJ, Punt CJ, Iannotti N, Saidman BH, Sabbath KD, Gabrail NY, Picus J, Morse M, Mitchell E, Miller MC, Doyle GV, Tissing H, Terstappen LW, Meropol NJ: Relationship of circulating tumor cells to tumor response, progression-free survival, and overall survival in patients with metastatic colorectal cancer. J Clin Oncol 2008;26:3213-3221.

80 Goldkorn A, Ely B, Quinn DI, Tangen CM, Fink LM Xu T, Twardowski P, Van Veldhuizen PJ, Agarwal N, Carducci MA, Monk JP 3rd, Datar RH, Garzotto M, Mack PC, Lara P Jr, Higano CS, Hussain M, Thompson IM Jr, Cote RJ, Vogelzang NJ: Circulating tumor cell counts are prognostic of overall survival in SWOG S0421: a phase III trial of docetaxel with or without atrasentan for metastatic castration-resistant prostate cancer. J Clin Oncol 2014;32:1136-1142.

81 Khan MS, Kirkwood A, Tsigani T, Garcia-Hernandez J, Hartley JA, Caplin ME, Meyer T: Circulating tumor cells as prognostic markers in neuroendocrine tumors. J Clin Oncol 2013;31:365-372.

82 Lecomte T, Berger A, Zinzindohoue F, Micard S, Landi B, Blons H, Beaune P, Cugnenc PH, Laurent-Puig P: Detection of free-circulating tumor-associated DNA in plasma of colorectal cancer patients and its association with prognosis. Int J Cancer 2002;100:542-548.

83 Tie J, Wang Y, Tomasetti C, Li L, Springer S, Kinde I, Silliman N, Tacey M, Wong HL, Christie M, Kosmider S, Skinner I, Wong R, Steel M, Tran B, Desai J, Jones I, Haydon A, Hayes T, Price TJ, Strausberg RL, Diaz LA Jr, Papadopoulos N, Kinzler KW, Vogelstein B, Gibbs P: Circulating tumor DNA analysis detects minimal residual disease and predicts recurrence in patients with stage II colon cancer. Sci Transl Med 2016;8: 346ra392.

84 Santiago-Walker A, Gagnon R, Mazumdar J, Casey M, Long GV, Schadendorf D, Flaherty K, Kefford R, Hauschild A, Hwu P, Haney P, O'Hagan A, Carver J, Goodman V, Legos I, Martin AM: Correlation of BRAF mutation status in circulating-free DNA and tumor and association with clinical outcome across four BRAFi and MEKi clinical trials. Clin Cancer Res 2016;22:567-574.

85 Peinado H, Aleckovic M, Lavotshkin S, Matei I, CostaSilva B, Moreno-Bueno G, Hergueta-Redondo M, Williams C, Garcia-Santos G, Ghajar C, Nitadori-Hoshino A, Hoffman C, Badal K, Garcia BA, Callahan MK, Yuan J, Martins VR, Skog J, Kaplan RN, Brady MS, Wolchok JD, Chapman PB, Kang Y, Bromberg J, Lyden D: Melanoma exosomes educate bone marrow progenitor cells toward a pro-metastatic phenotype through met. Nat Med 2012;18:883-891. 